\title{
Assessments on growth and morphological attributes of bud wood nursery plants of rubber in different agro-climatic regions of Sri Lanka
}

\author{
R.Handapangoda ${ }^{1}$, P.Seneviratne ${ }^{1}$, N.M.C.Nayanakantha ${ }^{1}$, and S.Subasinghe ${ }^{2}$ \\ ${ }^{I}$ Rubber Research Institute, Dartonfield, Agalawatta, Sri Lanka \\ ${ }^{2}$ Departement of Crop Science, Faculty of Agriculture, University of Ruhuna, Mapalana, Kamburupitiya, Sri
}

Lanka.

\begin{abstract}
The present study was undertaken to ascertain the growth, morphological and bud grafting performance of eight rubber clones viz. RRIC 100, RRIC 102, RRIC 121, RRISL 203, RRISL 217, RRISL 2001, $P B 86$ and PB 260 in bud wood nurseries established in Egaloya (wet zone) and Ampara (dry zone) of Sri Lanka. Root stock nurseries were established in Egaloya, Ampara and Moneragala (intermediate zone). The clone RRIC 121 recorded the highest growth rate and number of usable buds followed by RRISL 2001 and RRISL 203 and the lowest in RRIC 102 followed by RRISL 217in bud wood nurseries established in both Egaloya and Ampara. RRIC 121 showed the highest bud grafting success in Moneragala, while RRIC 102 in Egaloya and PB 260 in Ampara. Nevertheless, the clone RRISL 203 ranked the lowest for the same attribute in Moneragala while RRIC 100 in Ampara and Egaloya respectively.
\end{abstract}

Keywords: Rubber clones, bud grafting, young budding, growth, morphological characters, Agro Climatic Regions

\section{Introduction}

Rubber, one of the major plantation crops grlown in Sri Lanka, plays a vital role in the economy. The land area under rubber is 135,000 ha and the total production was 89,000 Mt in the year 2015[1]. Foreign exchange earning of country in the year 2014 was 122 billion rupees [2]. Production of high quality vigorous planting materials is essential for establishing rubber cultivation. Over 4 million budded plants are produced annually from government, Regional Plantation Company owned and private nurseries.

Ground nurseries are not recommended for budded plant production of rubber due to producing weak plants very often and no one taking responsibility for the quality of the budded plant. Early germinated seeds are transplanted to 300 or 500 gagged, gusseted and perforated black polythene bag (poly bag) and it is the most advanced method today.

Only young budding technique is used for planting material production since 2004. The technique has first been introduced into plantations in 1985 [3] and since then, it has been widely accepted by planters because of the low cost of production than for other poly bag planting material such as brown and green budding and the high quality of the plant. In fact, young budding is an improvement made on green budding where seedlings in poly bags are grafted when they are only 3-4 months old and two whorled budded plants are ready for planting in about 9-10 months.

As young budding plants are raised in poly bags, they have all the advantages that a poly bag plant could have. Moreover, unlike in other planting material, almost all the inputs that usually go to raise the stock plant are diverted to scion growth, in young budding as seedling plant is grafted when it is success and field planted before they are less than one year.

Yield potential of rubber varies even within the clone. High quality and vigorous plants always give high growth and yield performances. According to Antony [4] and Mydin [5] growth at early stage determines growth at maturity and vigor as well as timber yield. If the growth rate of a plant is higher, it will lead to increase latex yield. Comparative growth of rubber plants can be obtained by recommended practices as recorded by Seneviratne [6]. According to Sethuraj [7] and Paardekooper [8], the growth of plants is the most important parameter for evaluating the maturity of the plantations in relation to harvesting the latex.

Several studies have been done with regard to factors affecting bud wood quality and the bud grafting success ([6], [9] and [10]). Various growth parameters such as plant height, collar diameter, number of leaf whorls and leaves etc. are the important morphological traits for considering the plant vigor [11]. According to Chandra et al [12], there are clonal variations for almost all characters and they influence on early vigor in terms of growth and growth increments. So far studies have not been conducted in Sri Lanka to evaluate the growth performances of bud wood of different clones which influence the scion growth of budded plants. 
Planting materials play a vital role for productivity improvement and sustainability in rubber plantations. High quality young budded plants always show better performances. However, growth, morphological and physiological parameters of bud wood nursery plants which affect growth of budded plants should be identified in order to improve the quality. Therefore, this study was undertaken to evaluate the growth and morphological attributes of bud wood plants of different clones with special reference to bud grafting success.

\subsection{Nurseries}

\section{Materials and Methods}

Bud wood nurseries were established in the government rubber nursery at Egaloya $\left(\mathrm{WL}_{1 \mathrm{a}}\right)$ and in Civil Security Force training school at Inginiyagala, Ampara $\left(\mathrm{DL}_{2 \mathrm{a}}\right)$.In this study, assessments on bud wood nurseries and bud grafting procedures were done for eight clones viz.PB 86, PB 260, RRIC 100, RRIC 102, RRIC 121, RRISL 203, RRISL 217 and RRISL 2001.320 plants (forty plants per clone) were established in 2014 as bud wood nurseries according to a Randomized Complete Block Design (RCBD). Stock nurseries of 1000 plants were established separately at Egaloya $\left(\mathrm{WL}_{1 \mathrm{a}}\right)$, Ampara $\left(\mathrm{DL}_{2 \mathrm{a}}\right)$ and Moneragala $\left(\mathrm{IL}_{1 \mathrm{c}}\right)$ in 2015.Manuring and agronomic practices for bud wood and stock nurseries were done as recommended by RRISL.

\subsection{Measurement of growth parameters of bud wood nursery plants}

Growth and morphological attributes viz. girth, height, length of internodes, number of bud patches, number of leaves, number of leaf whorls, leaf angle and chlorophyll content were recorded at monthly intervals before and after pollarding.

\subsection{Bud grafting}

Stock plants were bud grafted when they reached $6-9 \mathrm{~mm}$ diameter at $1 \mathrm{~cm}$ from the base and the success rate was recorded 21 days after bud grafting.

\subsection{Data analyze}

Data was analyzed using SAS (version 9.1) package. Significant mean were separated using Duncan Multiple range Test (DMRT) at the 5\% probability level.

\subsection{Characters of bud wood nurseries}

\section{Results and Discussion}

Clonal characters of bud wood nursery plants varied under different climatic conditions. However those results may be utilize to select the best performing clones for different agro climatic regions in Sri Lanka. Similar studies for growth and morphological performances have been conducted by Antony [4] and Krishan [13] in India. According to Nugawela [14], juvenile rubber plants could be used to predict the genotype differences in parameter related to the yield determinates in their mature.

Table 1.Diameter and height increment and second inter node length of the bud wood plants of different clones after 10 months of planting

\begin{tabular}{|c|c|c|c|c|c|c|}
\hline \multirow[t]{2}{*}{ Clone } & \multicolumn{2}{|c|}{$\begin{array}{l}\text { Diameter increment (mm) } \\
\text { (Sep.2015-Jan.2016) }\end{array}$} & \multicolumn{2}{|c|}{$\begin{array}{l}\text { Height increment }(\mathrm{cm})(\text { Sep.2015- } \\
\text { Jan.2016) }\end{array}$} & \multicolumn{2}{|c|}{ Second internode length $(\mathrm{cm})$} \\
\hline & Egaloya & Ampara & Egaloya & Ampara & Egaloya & Ampara \\
\hline $\mathrm{PB} 86$ & $7.43^{\mathrm{b}}$ & $7.70^{\mathrm{bc}}$ & $84.36^{\mathrm{b}}$ & $84.04^{\mathrm{a}}$ & $11.59^{\mathrm{bc}}$ & $10.45^{\mathrm{c}}$ \\
\hline PB 260 & $8.61^{\mathrm{a} b}$ & $7.46^{\mathrm{bc}}$ & $100.45^{\mathrm{ab}}$ & $59.12^{\mathrm{d}}$ & $17.34^{\mathrm{a}}$ & $12.25^{\mathrm{b}}$ \\
\hline RRIC 100 & $10.22^{\mathrm{a}}$ & $8.04^{\mathrm{abc}}$ & $38.36^{\mathrm{c}}$ & $67.41^{\mathrm{cd}}$ & $11.81^{\mathrm{bc}}$ & $11.47^{\mathrm{co}}$ \\
\hline RRIC 102 & $7.61^{\mathrm{b}}$ & $8.33^{\mathrm{a} \mathrm{c}^{-}}$ & $27.81^{\mathrm{c}}$ & $75.97^{\mathrm{c}}$ & $19.09^{\mathrm{a}}$ & $17.47^{\mathrm{a}}$ \\
\hline RRIC 121 & $9.46^{\mathrm{ab}}$ & $9.02^{\mathrm{a}}$ & $111.73^{\mathrm{a}}$ & $103.62^{\mathrm{a}}$ & $13.61^{\mathrm{b}}$ & $12.41^{\mathrm{b}}$ \\
\hline RRISL 203 & $8.46^{\mathrm{ab}}$ & $8.46^{\mathrm{ab}}$ & $82.64^{\mathrm{b}}$ & $80.46^{\mathrm{bc}}$ & $10.18^{\mathrm{cd}}$ & $9.36^{\mathrm{cb}}$ \\
\hline RRISL 217 & $7.29^{\mathrm{b}}$ & $5.50^{\mathrm{d}}$ & $80.71^{\mathrm{b}}$ & $58.40^{\mathrm{d}^{-}}$ & $12.10^{\mathrm{cb}^{-}}$ & $9.66^{\mathrm{cb}}$ \\
\hline RRISL 2001 & $8.46^{\mathrm{ab}}$ & $7.34^{\mathrm{c}}$ & $94.93^{\mathrm{ab}}$ & $77.32^{\mathrm{cb}}$ & $8.21^{\mathrm{d}}$ & $8.71^{\mathrm{c}}$ \\
\hline
\end{tabular}

Means with the same letter in a column are not significantly different at $p \leq 0.05$

The highest diameter was recorded for RRIC100 at Egaloya while that was in RRIC 121 in Ampara. RRISL217, RRIC 102 and PB 86 in wet zone and RRISL217 in dry zone showed the lowest diameter increment. The clone RRIC 121 showed the highest stem height at Egaloya whereas RRIC 121 and PB 86 showed the highest in Ampara respectively. The lowest values were recorded from RRIC 100and RRIC 102 at Egaloya and RRISL 217 in Ampara. As shown in Table 1a low girth was recorded from plants in Ampara as compared to those at Egaloya, possibly due to high temperature and drought conditions prevailed in Ampara during the study 
Assessments on growth and morphological attributes of bud wood nursery plants of rubber in..

period. The maximum internodel length was recorded for RRIC 102 and PB 260 in wet zone and RRI 102 in dry zone which is an important character of plant growth. The lowest value for both areas was recorded for RRISL 2001(Table 1).

Table 2.Number of shoots and leaf whorls of bud wood plants before pollarding in 8 clones grown under different agro-climatic conditions.

\begin{tabular}{lllll}
\hline \multirow{2}{*}{ Clone } & \multicolumn{2}{c}{ No.of shoots } & \multicolumn{2}{c}{ No.of leaf whorls/plant } \\
\cline { 2 - 5 } & Egaloya & Ampara & Egaloya & Ampara \\
\hline PB 86 & $3.53^{\mathrm{c}}$ & $0.84^{\mathrm{d}}$ & $7.65^{\mathrm{a}}$ & $8.45^{\mathrm{a}}$ \\
PB 260 & $5.10^{\mathrm{c}}$ & $3.21 \mathrm{~b}^{\mathrm{c}}$ & $6.58^{\mathrm{b}}$ & $6.48^{\mathrm{c}}$ \\
RRIC 100 & $7.73^{\mathrm{b}}$ & $3.37 \mathrm{~b}^{\mathrm{c}}$ & $5.28^{\mathrm{c}}$ & $6.45^{\mathrm{c}}$ \\
RRIC 102 & $10.60^{\mathrm{a}}$ & $8.59^{\mathrm{a}}$ & $5.28^{\mathrm{c}}$ & $6.50^{\mathrm{c}}$ \\
RRIC 121 & $7.83^{\mathrm{b}}$ & $4.08^{\mathrm{b}}$ & $7.35^{\mathrm{a}}$ & $8.31^{\mathrm{a}}$ \\
RRISL 203 & $7.08^{\mathrm{b}}$ & $4.85^{\mathrm{b}}$ & $6.15^{\mathrm{b}}$ & $7.43^{\mathrm{b}}$ \\
RRISL 217 & $7.45^{\mathrm{b}}$ & $3.83^{\mathrm{b}}$ & $7.65^{\mathrm{a}}$ & $7.50^{\mathrm{b}}$ \\
RRISL 2001 & $4.25^{\mathrm{c}}$ & $1.79^{\mathrm{cd}}$ & $7.20^{\mathrm{a}}$ & $7.69^{\mathrm{b}}$ \\
\hline
\end{tabular}

Means with the same letter in a column are not significantly different at $\mathrm{p} \leq 0.05$

According to the Table 2, RRIC 102 recorded the highest number of shoots irrespective of the zones while the lowest was recorded forPB86, PB 260 and RRISL 2001 at Egaloya and PB86 in Ampara respectively. However, number of leaf whorls was higher in PB86, RRIC 121, RRISL217 and RRISL 2001 in wet zone while PB 86 and RRIC 121 in Dry zone. Nevertheless, both RRIC 100 and RRIC 102 in the wet zone and PB 260, RRIC 100 and RRIC 102 in the dry zone recorded the lowest.

Morphological and physiological attributes of clones such as bud breaking, chlorophyll content of leaf, time taken to mature the first and the second leaf whorls after pollarding would provide information to plan the bud grafting programme of rubber nurseries. Bud breaking was earlier in clone RRIC 102 at Egaloya and RRISL 217 in Ampara. However PB 86 and RRISL 217 in wet zone and RRIC 100 in Ampara took more time for bud breaking (Table 3).

There was no significant difference in number of shoots for any clone at Egaloya. But in Ampara, the maximum number of shoots was recorded from PB 86 and RRIC 102 while RRISL 2001 showed the lowest. The lowest number of leaf whorls was recorded from RRIC102 and PB 260 in both areas. However, PB 86, RRIC 121, RRISL 217 and RRISL 2001 in wet zone and PB 86and RRIC 121 in dry zone recorded the highest number of green buds. PB 86 at Egaloya and RRISL 217 in Ampara showed the highest shoot angle and RRIC 100 in both areas showed the lowest.

According to the Table 3, chlorophyll content did not vary significantly among clones at Egaloya. But clone PB 260, RRIC 121, RRISL 203 and RRISL 2001 indicated the highest chlorophyll content and PB 86, RRIC 100, RRIC 102 and RRISL 217 showed the lowest in Ampara.

RRIC 102 and RRISL 217 took the maximum time and RRIC 121 and RRISL 203 took minimum for the first whorl to mature at Egaloya while there was no significant difference in time taken to mature first leaf whorl in Ampara. PB 260 and RRIC 102 at Egaloya and only PB 260 in Ampara recorded the maximum time and RRIC 121 in both areas took the minimum time for the second leaf whorl to mature.

The variation of morphology and growth of bud wood nursery plants at three whorl stage are shown in Table 4. As far as the first internode was concerned, RRIC 102 showed the highest length in wet zone. However, in Ampara, PB 260, RRIC 102 and RRIC 121 showed the highest length. PB 86, RRIC 100 and RRISL 2001 at Egaloya and PB 86, RRIC 100, RRISL 203, RRISL 217 and RRISL 2001 in Ampara showed the lowest.

More number of bud patches in the first internode was observed in RRIC 121 and lesser was observed in PB 86, RRIC 100 and RRISL 217 at Egaloya. RRISL 203 and RRICE 100 showed the highest and the lowest number of bud patches in Ampara respectively. The highest number of leaves in first internode at Egaloya was recorded from PB 260 and RRISL 203 while PB 86, RRIC 102, RRISC 121 and RRISL 217 showed the lowest. In Ampara RRISL 2001 and RRISL 217 recorded the highest and the lowest values separately.

In the second internode, the highest length was recorded from RRIC 121 at Egaloya and RRIC 102 in Ampara while RRISL 203 showed the lowest in both areas. RRIC 121, RRISL 203 and RRISL 2001 at Egaloya and RRIC 121 in Ampara were rich in bud patches and they were lesser in RRISL 217 at two sites. The highest 
Assessments on growth and morphological attributes of bud wood nursery plants of rubber in..

number of leaves in the second internode was recorded from PB 260 while PB 86 and RRIC 102 showed the lowest at Egaloya. Number of leaves of the second internode in Ampara was rich in PB 260, RRIC 100, RRIC 102 and RRISL 2001 while RRISL 217 showed the lowest.

In the third internode, PB 86 showed the highest length while RRIC 100 and RRISL 203 showed the lowest at Egaloya. In Ampara RRIC 102 recorded the highest length and RRISL 217 recorded the lowest. In wet zone more number of bud patches was recorded from PB 260, RRIC 100, RRIC 121, RRISL 203 and RRISL 2001 while RRIC 102 showed the lowest. In Ampara RRIC 121 recorded the maximum number of bud patches and PB 86, RRIC 100 and RRIC 102 showed the lowest. Higher number of leaves was recorded from PB 260 while PB 86, RRIC100, RRIC 102 and RRISL 217recorded the lowest in the wet zone. Number of leaves was more in PB 260, RRIC 102, RRIC 121, RRISL 203 and RRISL 2001 in dry area. PB 86, RRIC 100 and RRISL 217 showed the lesser number of leaves in this zone.

Table 3:Time taken for bud breaking and maturing of the first and the second leaf whorls, no. of shoots, leaf whorls, angle of shoot and chlorophyll content of the clones after pollarding.

\begin{tabular}{|c|c|c|c|c|c|c|c|c|c|c|c|c|c|c|}
\hline \multirow[t]{2}{*}{ Clone } & \multicolumn{2}{|c|}{$\begin{array}{l}\text { Time taken for bud } \\
\text { breaking (days) }\end{array}$} & \multicolumn{2}{|c|}{ No. of shoots/plant } & \multicolumn{2}{|c|}{$\begin{array}{l}\text { No. of leaf } \\
\text { whorls/shoot }\end{array}$} & \multicolumn{2}{|c|}{ Angle of shoot } & \multicolumn{2}{|c|}{$\begin{array}{l}\text { Chlorophyll } \\
\text { content of leaf }\end{array}$} & \multicolumn{2}{|c|}{$\begin{array}{l}\text { Time taken for } \\
\text { maturing the first } \\
\text { whorl (months) }\end{array}$} & \multicolumn{2}{|c|}{$\begin{array}{l}\text { Time taken for } \\
\text { maturing the second } \\
\text { whorl (months) }\end{array}$} \\
\hline & 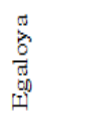 & $\begin{array}{l}\frac{\tilde{g}}{\mathrm{G}} \\
\text { है } \\
\text { दे }\end{array}$ & 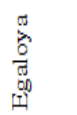 & $\begin{array}{l}\frac{\pi}{\tilde{E}} \\
\frac{0}{E} \\
\dot{z}\end{array}$ & 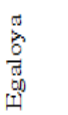 & $\begin{array}{l}\text { हुँ } \\
\text { है } \\
\text { दे }\end{array}$ & 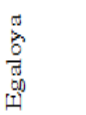 & $\begin{array}{l}\frac{\pi}{\tilde{g}} \\
\text { है } \\
\text { दे }\end{array}$ & 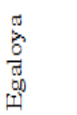 & $\begin{array}{l}\frac{\pi}{G} \\
\stackrel{a}{E} \\
\vdots\end{array}$ & 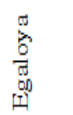 & $\begin{array}{l}\frac{\pi}{\vec{g}} \\
\text { है } \\
\text { दे }\end{array}$ & 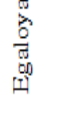 & $\begin{array}{l}\frac{\pi}{\vec{g}} \\
\stackrel{0}{E} \\
\vdots\end{array}$ \\
\hline $\mathrm{PB} 86$ & $9.35^{\mathrm{a}}$ & $7.42^{\mathrm{abc}}$ & $6.39^{\mathrm{a}}$ & $8.62^{\mathrm{a}}$ & $1.99^{\mathrm{a}}$ & $1.83^{\mathrm{a}}$ & $57.12^{\mathrm{a}}$ & $38^{\mathrm{sb}}$ & $57.73^{\mathrm{a}}$ & $49.37^{b}$ & $1.35^{\mathrm{ab}}$ & $1.36^{\mathrm{a}}$ & $2.35^{\mathrm{bc}}$ & $2.51^{\text {cd }}$ \\
\hline PB 260 & $8.86^{\mathrm{ab}}$ & $7.33^{b c}$ & $4.40^{\mathrm{a}}$ & $6.77^{\circ}$ & $1.72^{\mathrm{b}}$ & $1.22^{\mathrm{d}}$ & $47.44^{\mathrm{cd}}$ & $38.23^{\circ}$ & $59.16^{\mathrm{a}}$ & $55.75^{\mathrm{a}}$ & $1.34^{\mathrm{ab}}$ & $1.58^{\mathrm{a}}$ & $2.70^{\mathrm{a}}$ & $2.75^{\mathrm{a}}$ \\
\hline RRIC 100 & $7.76^{\circ}$ & $9.38^{\mathrm{a}}$ & $4.60^{\mathrm{a}}$ & $8.13^{\mathrm{abc}}$ & $1.87^{\mathrm{ab}}$ & $1.47^{\circ}$ & $42.56^{\mathrm{e}}$ & $29.96^{\mathrm{d}}$ & $57.61^{\mathrm{a}}$ & $52.40^{\mathrm{b}}$ & $1.33^{\mathrm{ab}}$ & $1.55^{\mathrm{a}}$ & $2.42^{\mathrm{b}}$ & $2.54^{\text {bcd }}$ \\
\hline RRIC 102 & $6.86^{\mathrm{d}}$ & $8.00^{\mathrm{ab}}$ & $5.00^{\mathrm{a}}$ & $5.25^{\mathrm{d}}$ & $1.67^{\mathrm{b}}$ & $1.15^{\mathrm{d}}$ & $46.43^{\mathrm{d}}$ & $34.33^{\circ}$ & $56.10^{\mathrm{a}}$ & $49.64^{\mathrm{b}}$ & $1.42^{\mathrm{a}}$ & $1.54^{\mathrm{a}}$ & $2.67^{\mathrm{a}}$ & $2.68^{\mathrm{ab}}$ \\
\hline RRIC 121 & $8.48^{\mathrm{abc}}$ & $7.13^{b c}$ & $4.08^{\mathrm{a}}$ & $8.53^{\mathrm{ab}}$ & $1.97^{\mathrm{a}}$ & $1.80^{\mathrm{a}}$ & $49.87^{\mathrm{bc}}$ & $42.21^{\mathrm{b}}$ & $58.86^{\mathrm{a}}$ & $55.62^{\mathrm{a}}$ & $1.32^{\mathrm{b}}$ & $1.42^{\mathrm{a}}$ & $2.29^{\circ}$ & $2.48^{\mathrm{d}}$ \\
\hline RRISL 203 & $8.08^{\mathrm{bc}}$ & $8.60^{\mathrm{ab}}$ & $10.63^{\mathrm{a}}$ & $7.36^{b c}$ & $1.88^{\mathrm{ab}}$ & $1.577^{\mathrm{bc}}$ & $49.17 \mathrm{bcd}$ & $35.64^{\circ}$ & $57.04^{\mathrm{a}}$ & $56.41^{\mathrm{a}}$ & $1.32^{\mathrm{b}}$ & $1.50^{\mathrm{a}}$ & $2.36^{\mathrm{bc}}$ & $2.67^{\mathrm{abc}}$ \\
\hline RRISL 217 & $9.07^{\mathrm{a}}$ & $5.56^{\mathrm{c}}$ & $5.69^{\mathrm{a}}$ & $8.58^{\mathrm{ab}}$ & $1.92^{\mathrm{a}}$ & $1.73^{\mathrm{ab}}$ & $51.21^{\mathrm{b}}$ & $48.31^{\mathrm{a}}$ & $57.51^{\mathrm{a}}$ & $51.35^{b}$ & $1.41^{\mathrm{s}}$ & $1.40^{\mathrm{a}}$ & $2.39^{\mathrm{bc}}$ & $2.51^{\mathrm{dc}}$ \\
\hline RRISL2001 & $8.88^{\circ}$ & $6.67 \mathrm{bc}$ & $4.44^{\mathrm{a}}$ & $4.79^{\mathrm{d}}$ & $1.93^{\mathrm{a}}$ & $1.68^{\mathrm{sb}}$ & $47.63^{\mathrm{cd}}$ & $35.33^{\mathrm{c}}$ & $57.56^{\mathrm{a}}$ & $56.27^{\mathrm{a}}$ & $1.35^{\mathrm{ab}}$ & $1.57^{\mathrm{a}}$ & $2.34^{\mathrm{bc}}$ & $2.61^{\mathrm{sbcd}}$ \\
\hline
\end{tabular}

Means with the same letter in a column are not significantly different at $\mathrm{p} \leq 0.05$

Table 4: Lengths, no of bud patches and no. of leaves of the clones in three whorls stage of bud wood.

\begin{tabular}{|c|c|c|c|c|c|c|c|c|c|}
\hline & \multicolumn{3}{|c|}{$1^{\text {st }}$ Internode } & \multicolumn{3}{|c|}{$2^{\text {nd }}$ Internode } & \multicolumn{3}{|c|}{$3^{\text {rd }}$ Internode } \\
\hline Clone & $\begin{array}{l}\text { Length } \\
\text { (cm) }\end{array}$ & $\begin{array}{l}\text { No. of bud } \\
\text { patches }\end{array}$ & $\begin{array}{l}\text { No. of } \\
\text { leaves }\end{array}$ & $\begin{array}{l}\text { Length } \\
\text { (cm) }\end{array}$ & $\begin{array}{c}\text { No. of bud } \\
\text { patches }\end{array}$ & $\begin{array}{l}\text { No. of } \\
\text { leaves }\end{array}$ & $\begin{array}{l}\text { Length } \\
\text { (cm) }\end{array}$ & $\begin{array}{c}\text { No. of } \\
\text { bud } \\
\text { patches }\end{array}$ & $\begin{array}{l}\text { No. of } \\
\text { leaves }\end{array}$ \\
\hline \multicolumn{10}{|l|}{ Egaloya } \\
\hline PB 86 & $28.20^{b}$ & $3.75^{\mathrm{d}}$ & $10.50^{\mathrm{c}}$ & $46.35^{\mathrm{ab}}$ & $5.25^{b}$ & $13.50^{\mathrm{c}}$ & $52.53^{\mathrm{a}}$ & $6.25^{\mathrm{ab}}$ & $15.10^{\mathrm{c}}$ \\
\hline PB 260 & $36.65^{\mathrm{ab}}$ & $5.10^{\mathrm{c}}$ & $14.00^{\mathrm{a}}$ & $41.48^{\mathrm{ab}}$ & $5.55^{\mathrm{b}}$ & $16.20^{\mathrm{a}}$ & $50.43^{\mathrm{ab}}$ & $7.30^{\mathrm{a}}$ & $21.45^{\mathrm{a}}$ \\
\hline RRIC 100 & $27.13^{b}$ & $4.35^{\mathrm{d}}$ & $10.80^{\mathrm{bc}}$ & $41.38^{\mathrm{ab}}$ & $5.20^{b}$ & $14.80^{\mathrm{abc}}$ & $35.03^{\mathrm{d}}$ & $7.75^{\mathrm{a}}$ & $15.35^{\mathrm{c}}$ \\
\hline RRIC 102 & $44.58^{\mathrm{a}}$ & $5.15^{\mathrm{bc}}$ & $10.55^{\mathrm{c}}$ & $54.60^{\mathrm{ab}}$ & $5.45^{\mathrm{b}}$ & $13.00^{c}$ & $35.83^{\text {cd }}$ & $5.78^{b}$ & $14.56^{\mathrm{c}}$ \\
\hline RRIC 121 & $31.53^{\mathrm{ab}}$ & $6.00^{\mathrm{a}}$ & $10.35^{\mathrm{c}}$ & $58.15^{\mathrm{a}}$ & $6.80^{\mathrm{a}}$ & $14.00^{\mathrm{bc}}$ & $51.80^{\mathrm{ab}}$ & $7.60^{\mathrm{a}}$ & $18.35^{\mathrm{b}}$ \\
\hline RRISL 203 & $35.13^{\mathrm{ab}}$ & $5.80^{\mathrm{ab}}$ & $13.65^{\mathrm{a}}$ & $33.93^{b}$ & $6.25^{\mathrm{a}}$ & $14.75^{a b c}$ & $33.45^{\mathrm{d}}$ & $7.45^{\mathrm{a}}$ & $16.50^{\mathrm{bc}}$ \\
\hline RRISL 217 & $39.00^{\mathrm{ab}}$ & $3.95^{\mathrm{d}}$ & $9.65^{\mathrm{c}}$ & $45.93^{\mathrm{ab}}$ & $4.30^{\mathrm{c}}$ & $14.70^{\text {abc }}$ & $43.73^{\mathrm{bc}}$ & $6.70^{\mathrm{ab}}$ & $15.20^{\mathrm{c}}$ \\
\hline RRISL 2001 & $29.00^{b}$ & $5.35^{a b c}$ & $12.40^{\mathrm{ab}}$ & $38.75^{\mathrm{ab}}$ & $6.35^{\mathrm{a}}$ & $15.55^{\mathrm{ab}}$ & $37.38^{\mathrm{cd}}$ & $7.75^{\mathrm{a}}$ & $16.65^{\mathrm{bc}}$ \\
\hline \multicolumn{10}{|l|}{ Ampara } \\
\hline PB 86 & $25.88^{b}$ & $4.35^{\mathrm{d}}$ & $9.29^{\mathrm{bc}}$ & $38.38^{\mathrm{ab}}$ & $5.41^{\mathrm{c}}$ & $10.94^{\mathrm{ab}}$ & $35.43^{\mathrm{abc}}$ & $5.27^{d}$ & $11.67^{b}$ \\
\hline PB 260 & $28.09^{\mathrm{a}}$ & $4.76^{\mathrm{cd}}$ & $10.47^{\mathrm{abc}}$ & $33.59^{\mathrm{bc}}$ & $5.12^{\text {cd }}$ & $12.12^{\mathrm{a}}$ & $34.70^{\mathrm{abc}}$ & $5.40^{\mathrm{cd}}$ & $15.00^{\mathrm{a}}$ \\
\hline RRIC 100 & $25.32^{\mathrm{b}}$ & $5.10^{\mathrm{c}}$ & $9.26^{\mathrm{bc}}$ & $33.08^{\mathrm{bc}}$ & $6.63^{\mathrm{ab}}$ & $11.84^{\mathrm{a}}$ & $32.36^{\mathrm{bc}}$ & $5.29^{d}$ & $12.73^{b}$ \\
\hline RRIC 102 & $36.03^{\mathrm{a}}$ & $4.67^{\text {cd }}$ & $9.80^{\mathrm{abc}}$ & $41.87^{\mathrm{a}}$ & $5.13^{\mathrm{cd}}$ & $11.60^{\mathrm{a}}$ & $42.00^{\mathrm{a}}$ & $5.25^{\mathrm{d}}$ & $14.83^{\mathrm{a}}$ \\
\hline RRIC 121 & $33.23^{\mathrm{a}}$ & $5.70^{b}$ & $10.65^{\mathrm{ab}}$ & $34.50^{\mathrm{abc}}$ & $7.15^{\mathrm{a}}$ & $11.80^{\mathrm{a}}$ & $36.25^{\mathrm{ab}}$ & $6.90^{\mathrm{a}}$ & $15.20^{\mathrm{a}}$ \\
\hline RRISL 203 & $28.15^{\mathrm{b}}$ & $6.65^{\mathrm{a}}$ & $10.15^{\mathrm{abc}}$ & $23.10^{\mathrm{d}}$ & $6.35^{\mathrm{ab}}$ & $10.50^{\mathrm{ab}}$ & $31.39^{\mathrm{bc}}$ & $6.33^{\mathrm{ab}}$ & $15.06^{\mathrm{a}}$ \\
\hline RRISL 217 & $24.84^{\mathrm{b}}$ & $4.63^{\mathrm{cd}}$ & $8.74^{\mathrm{c}}$ & $26.37^{\mathrm{cd}}$ & $4.53^{d}$ & $9.53^{\mathrm{b}}$ & $27.25^{\mathrm{c}}$ & $5.44^{\mathrm{cd}}$ & $11.39^{\mathrm{b}}$ \\
\hline RRISL 2001 & $26.80^{\mathrm{b}}$ & $5.95^{\mathrm{b}}$ & $11.30^{\mathrm{a}}$ & $26.63^{\mathrm{cd}}$ & $6.20^{\mathrm{b}}$ & $12.20^{\mathrm{a}}$ & $33.44^{\mathrm{abc}}$ & $5.94^{\mathrm{bc}}$ & $16.06^{\mathrm{a}}$ \\
\hline
\end{tabular}

Means with the same letter in a column are not significantly different at $\mathrm{p} \leq 0.05$ 
Two types of buds namely axillary and scale buds are found in bud wood. They affect the bud grafting success or the growth of scion although there are no differences between them ([9] and [15]). According to the Table 5, PB 260, RRIC 121, RRISL 203 and RRISL 2001 showed the highest number of scale buds in the first internode at Egaloya while PB 86 showed the lowest. In Ampara, RRIC 121 and RRISL 203 showed the highest number of scale buds while others recorded the lowest. There were no significant differences for axillary buds present on the first internode in bud wood nurseries in the wet zone. Nevertheless, PB 260, RRIC 121, RRISL 203 and RRISL 2001 showed the highest while PB 86, RRIC 100 and RRISL217 showed the lowest number of scale buds present on the first internode in the bud wood nurseries in the dry zone.

In the second internode, RRIC 121 in both areas showed the maximum numbers of scale buds while RRISL 217 in wet zone and RRISL 217 and RRIC 102 in dry zone showed the lowest. In the wet zone there was no significant difference for axillary buds among clones.

RRIC 121 at Egaloya showed the highest number of scale buds in the third internode and RRISL 217 showed the lowest. In Ampara, more scale buds were present in RRIC 100, RRIC 102, RRIC 121, RRISL 203 and RRISL 2001 while a lesser number was recorded in PB 86, PB 260 and RRISL 217.As far as the number of axillary buds is concerned, PB 260 at Egaloya and RRIC 102 and RRIC121 in Ampara recorded the highest. RRIC 100, RRIC 102, RRISL 203 and RRISL 217 in the wet zone and PB 86 in the dry zone showed the lowest.

\subsection{Bud grafting in different agro-climatic zones}

After establishing the stock nurseries, stock plants were maintained up to bud grafting stage. The highest bud grafting success was recorded from RRIC 102, RRIC 121 and PB 260 at Egaloya, Moneragala and Ampara respectively. RRIC 100 showed the lowest bud grafting success in both the wet and the dry zones whilst RRISL 203 showed the lowest in the intermediate zone (Fig. 1).

Table 5: Number of scale and axillary buds in the first, second and third internodes of different clones grown in wet and dry zones.

\begin{tabular}{|c|c|c|c|c|c|c|c|c|c|c|c|c|}
\hline \multirow[t]{3}{*}{ Clone } & \multicolumn{4}{|c|}{ First internode } & \multicolumn{4}{|c|}{ Second internode } & \multicolumn{4}{|c|}{ Third internode } \\
\hline & \multicolumn{2}{|c|}{ No. of scale buds } & \multicolumn{2}{|c|}{ No. of axillary buds } & \multicolumn{2}{|c|}{ No .of scale buds } & \multicolumn{2}{|c|}{ No of axillary buds } & \multicolumn{2}{|c|}{ No. of scale buds } & \multicolumn{2}{|c|}{ No. of axillary buds } \\
\hline & Egaloya & Ampara & Egaloya & Ampara & Egaloya & Ampara & Egaloya & Ampara & Egaloya & Ampara & Egaloya & Ampara \\
\hline PB 86 & $3.08^{c}$ & $3.08^{b}$ & $8.25^{\mathrm{a}}$ & $6.25^{b}$ & $4.25^{c}$ & $3.67 \mathrm{~cd}^{\mathrm{d}}$ & $12.00^{3}$ & $7.50^{\mathrm{ab}}$ & $5.75^{b c}$ & $3.30^{b}$ & $14.17 \mathrm{abc}$ & $8.30^{\circ}$ \\
\hline $\mathrm{PB} 260$ & $4.92^{\mathrm{a}}$ & $3.33^{b}$ & $9.83^{\mathrm{a}}$ & $8.58^{\mathrm{a}}$ & $4.836 \mathrm{c}$ & $3.75^{\mathrm{bcd}}$ & $12.83 \mathrm{a}$ & $8.33 \mathrm{ab}$ & $5.58 \mathrm{bc}$ & $3.11^{b}$ & $16.92^{\mathrm{a}}$ & $10.78^{\mathrm{ab}}$ \\
\hline RRIC 100 & $3.15 \mathrm{bc}$ & $3.33^{b}$ & $8.17^{\mathrm{a}}$ & $6.67 \mathrm{~b}$ & $4.836 \mathrm{c}$ & $4.58^{\mathrm{ab}}$ & $11.25^{\mathrm{a}}$ & $9.67^{\mathrm{a}}$ & $6.08^{b}$ & $4.00^{\mathrm{a}}$ & $12.42^{c}$ & $10.13 \mathrm{abc}$ \\
\hline RRIC 121 & $4.83^{\mathrm{a}}$ & $4.17^{\mathrm{a}}$ & $8.50^{3}$ & $8.50^{\mathrm{a}}$ & $5.92^{\mathrm{a}}$ & $4.75^{\mathrm{a}}$ & $12.08^{\mathrm{a}}$ & $8.50^{\mathrm{ab}}$ & $7.42^{\mathrm{a}}$ & $4.67^{\mathrm{a}}$ & $16.25^{\mathrm{ab}}$ & $11.83^{\mathrm{a}}$ \\
\hline RRISL 203 & $5.33^{\mathrm{a}}$ & $4.33^{\mathrm{a}}$ & $10.08^{3}$ & $8.25^{\mathrm{a}}$ & $5.33 \mathrm{~b}$ & $4.42^{2 \mathrm{bc}}$ & $11.42^{\mathrm{a}}$ & $6.92^{\mathrm{b}}$ & $6.67 \mathrm{bb}$ & $4.50^{\mathrm{a}}$ & $12.67^{\circ}$ & $10.67 \mathrm{ab}$ \\
\hline RRISL 217 & $3.42 \mathrm{co}$ & $2.92^{b}$ & $7.50^{3}$ & $5.92^{\mathrm{b}}$ & $3.58 \mathrm{~d}$ & $3.00^{\mathrm{d}}$ & $12.42 a$ & $7.58^{\mathrm{ab}}$ & $4.25^{\mathrm{d}}$ & 3.276 & $12.08^{\circ}$ & $8.73 b c$ \\
\hline RRISL 2001 & $5.41^{\mathrm{a}}$ & $3.42^{b}$ & $9.00^{\mathrm{a}}$ & $8.83^{\mathrm{a}}$ & $5.42^{\mathrm{bb}}$ & $4.33 \mathrm{abc}$ & $11.33^{\mathrm{a}}$ & $7.50^{\mathrm{ab}}$ & $6.42^{\mathrm{ab}}$ & $4.40^{\mathrm{a}}$ & $13.33^{b c}$ & $11.00^{\mathrm{ab}}$ \\
\hline
\end{tabular}

Means with the same letter in a column are not significantly different at $p \leq 0.05$

Means with the same letter in a column are not significantly different at $p \leq 0.05$

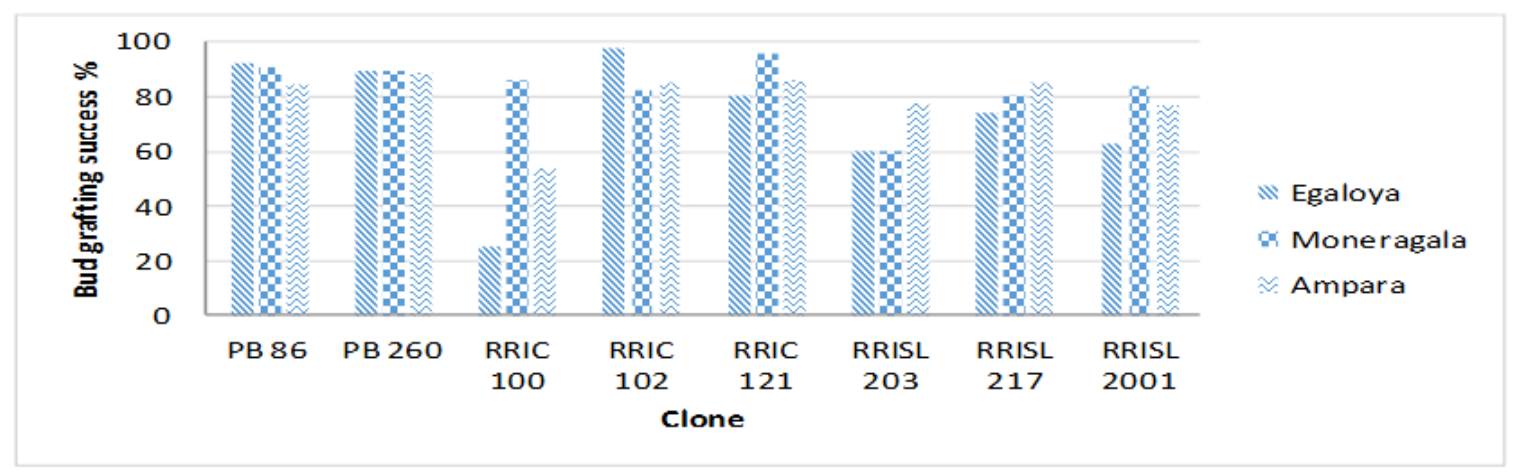

Figure 1. Bud grafting success of clone under varying agro-climatic regions.

\section{Conclusion}

Comparative results obtained from the present study lead to the identification of potential clones for commercial cultivation in varied agro- climatic regions. Preference to any clone depends on its quality and bud grafting success. The clonal composition of bud wood nurseries in the country is to be changed according to the climatic differences. Morphological and physiological factors of plants are more reliable for the measurements 
of growth attributes of rubber clones. Growth and morphological (clonal) characters of the budded plants and agro-climatic conditions are the factors governing the quality and the vigor of the planting materials and the production of quality budded rubber plants.

\section{References}

[1]. Anon, Annual Report, Central bank of Sri Lanka, National output of Expenditure and Income, 2015

[2]. Anon, Annual Report, Ministry of Plantation Industries, Statistical information of Plantation Crops, 2014.

[3]. S.K.Leong,P.K.Yoon,T.C.Ping, Use of young budding for improved Hevea cultivation. Proc. Int. Rubb. Conf. Kuala Lumpoor, 3, 1985,555

[4]. P.D.Antony, S.K.Dey and T.Meenakumari, Comparative growth and yield performance of Hevea clones under the agro climatic condition of Trtiputa .Natural Rubber Research, 23(1 \& 2), 2010, 12-10.

[5]. K.K.Mydin, Juvenile- mature correlations and association among rubber yield and yield attributes in Hevea braciliencis . Natural Rubber Research, 25(1), 2012, 1-12.

[6]. P.Seneviratne, A.Nugawela, S.M.A.Samarakoon, The role of snag on the growth of scion in bud grafted plants of Hevea with special reference to young buddings.,Jl.Rubb.Res.Ins. of Sri Lanka, 76, 1995, 21-35.

[7]. M.R.Sethuraj and M.J.George, (Ed.P.N.RadhakrishnaPillai). In.Handbook of Natural Rubber Research in India.The rubber Board Kottayan, India, 1980.

[8]. E.C.Paardekooper, Exploitation of the rubber tree. In. Rubber (Eds. C.C. Webster and W.J. Bawlwill). Longman Scientific and Technical England, 1989, 350-414.

[9]. P.Seneviratne,A.Nugawela. S.M.A.Samarakoon, Factors affecting the bud grafting success and the scion growth of young budding of Hevia,Jl.Rubb.Res.Ins. ofSri Lanka, 74, 1994,24-41.

[10]. P.Seneviratne, A.Nugawela, U.S.Weerakoon, M.N.de.Alwis, The effect of the condition of bud wood Nurseries on the Productivity: Mixed clones. Bulletin of the Rubber,Re.In.of Sri Lanka, 41, 2000, 44-49.

[11]. T.A.Soman, K.Kavitha and M.D.Jessy, Standardization of an alternative pottingmedium for raising Heveaplants in root trainer. Indian journal of Natural Rubber Research; 21(1), 2014, 69-77.

[12]. U.Chanda, SR.P.ingh, M.J.Reju, D.Ponda and P.Khogamthem, G.Dasand K.K.Mydy, Early growth Performances of Certain Hevea clones from on- farm trails in Garo Hills of Meghalaya, Rubber Science, 28(3), 2015, 275-280.

[13]. B.Krishan, Growth assessment of popular clones of natural rubber (Hevea brasiliencis) under warm dry climatic conditions of Chhattisgarh state Central India. Jl Experimental Biology and Agricultural Sciences. April, 2015, 3(2).

[14]. A.NugawelaGas exchange characterristics of Hevea genotypes and their use in selection for crop yield. Ph.D. thesis. University of Essex. U.K, 1989, 4.

[15]. P.Seneviratne, U.S.Weerakoon, M.N.de.Alwis and G.Karunarathne, A short account on the number of buds on various types of bud wood, Bulletin of the Rubber,Re.In.of Sri Lanka, 42, 2005, 25-28 Bulletin of the Rubber,Re.In.of Sri Lanka, 41, 2000, 44-49.

R. Handapangoda. "Assessments on growth and morphological attributes of bud wood nursery plants of rubber in different agro-climatic regions of Sri Lanka." IOSR Journal of Agriculture and Veterinary Science (IOSR-JAVS) 10.7 (2017): 21-26. 